\title{
Buzantes ou Buzantii
}

Voir Byzacium*/Byzacène

\section{(2) OpenEdition}

\section{Journals}

Édition électronique

URL : http://journals.openedition.org/encyclopedieberbere/2883

DOI : $10.4000 /$ encyclopedieberbere.2883

ISSN : 2262-7197

Éditeur

Peeters Publishers

Édition imprimée

Date de publication : 1 septembre 1992

Pagination : 1670

ISBN : 2-85744-581-4

ISSN : $1015-7344$

\section{Référence électronique}

«Buzantes ou Buzantii », Encyclopédie berbère [En ligne], 11 | 1992, document B1 18, mis en ligne le 01 avril 2013, consulté le 25 septembre 2020. URL : http://journals.openedition.org/encyclopedieberbere/ 2883 ; DOI : https://doi.org/10.4000/encyclopedieberbere.2883

Ce document a été généré automatiquement le 25 septembre 2020.

(c) Tous droits réservés 


\section{Buzantes ou Buzantii}

Voir Byzacium*/Byzacène 